\title{
The Abuse of Occupational Licensing
}

\author{
Walter Gellhorn $\dagger$
}

Occupational licensing is invariably justified as a means of protecting the public against incompetent and dishonest practitioners. The effect of mandatory licensure, however, is often to restrict entry into an occupation, thereby reducing competition among established members. Professor Gellhorn finds ample evidence that the proliferation of pseudo professions has adversely affected occupational mobility and economic competition, and warns that even such wellintended proposals as requiring the certification of lawyers with specialized practices may have similar consequences. He concludes that less restrictive forms of licensing should be employed to protect the public against shoddy or fraudulent services without curtailing occupational freedom.

In this bicentennial year devoted to celebrating American freedoms, literally hundreds of occupations are subject to licensing laws in one or more states. Possibly the founding fathers knew of restrictions in some of the new American states on the practices of law and medicine.' They would, however, have been aghast to learn that in many parts of this country today aspiring bee keepers, embalmers, lightning rod salesmen, septic tank cleaners, taxidermists, and tree surgeons must obtain official approval before seeking the public's patronage. ${ }^{2}$ After examining the roster of those who must receive official permission to function, a cynic might conclude that virtually the only people who remain unlicensed in at least one of the United States are clergymen and university professors, presumably because they are nowhere taken seriously.

$\dagger$ University Professor Emeritus, Columbia University. The author is happy to have an opportunity to join others in expressing esteem and affection for Kenneth C. Davis. Professor Davis's influence and forceful expressiveness in administrative law are unmatched in America. He richly deserves the respect which this issue of the Review signifies.

' Wallace, Occupational Licensing and Certification: Remedies for Denial, 14 WM. \& MARY L. Rev. 46, 46 n.1 (1972).

2 In 1969 West Virginia was the foremost adherent to "free enterprise," with only 63 occupations subject to licensure. California was the most restrictive, with 178 licensed occupations; Pennsylvania closely followed with 165 . K. Greene, Occupational Licensing and the Supply of Non-Professional Manpower 17 (Manpower Research Monograph No. 11, 1969). For a compilation of occupations subject to license, see $i d$. at 51. See also Council of State Governments, Occupations and Professions Licensed by the States (Pub. No. RM-422, 1968). Federal occupational licensing also exists, as in radio operation and stockyard services. W. Gellhorn, Individual Freedom and Governmental Restraints 106 (1956). 
A consideration of the proliferation of occupational license requirements is especially timely because it may help in evaluating two contemporary currents of public policy. First, prominent politicians and public officials assert that too much economic activity is subject to regulation; they urge "regulatory reform," a code phrase meaning the reduction of regulation. ${ }^{3}$ Second, within the legal profession demand is mounting for some formal means of identifying "specialists" among lawyers.

\section{The Beginnings of "Learned Professions"}

At one time the learned professions were those of theology, law, and medicine. Controversy will be avoided by accepting the hypothesis that theologians are and always have been learned. Considerable question may be raised, however, about the early belief that lawyers and doctors were learned, except perhaps on a comparative scale.

The American legal profession has been regarded as unassailably "learned" since the early immigrants set foot on Plymouth Rock more than 350 years ago. In actuality, the expounders of law in those distant times were small farmers and craftsmen who acted upon vagrant memories of local customs believed to have been enforced in England by some anonymous magistrate, coupled with notions of propriety derived from the Bible. When the colonists in 1636 codified their laws, their compilation was, as the late Julius Goebel has said, a "crude imitation of inaccurately remembered things." The same characterization can fairly be applied to legal developments throughout the colonies, but the crude imitators and inaccurate rememberers nevertheless maintained their status as learned. ${ }^{5}$

In 1636 a law book is believed to have arrived in Plymouth. In 1647 the Massachusetts legislature ordered six books on law from England - three of them by the same author-thus in a single stroke adding to colonial learning about the law by some six hundred percent. $^{6}$

Being learned in the law continued for some generations to be a popular pastime. A 1771 American edition of Blackstone's

${ }^{3}$ See, e.g., J. Sims, State Regulation and the Federal Antitrust Laws: The Justice Department's View of Licensing, August 4, 1975 (address given before National Council on Occupational Licensing in Virginia Beach, Va.)

+ Goebel, King's Law and Local Custom in Seventeenth Century New England, 31 Colum. L. Rev. 416, 434 (1931). But see G. Haskins, Law and Authority in Early MASSACHUSETTS 4-8 (1960).

5 See C. Hilkey, Legal Development in Colonial Massachusetts 65 (1910).

- Id. at 65-66. 
Commentaries on the Laws of England had 840 subscribers. ${ }^{7}$ While popular, the pursuit of legal learning was not particularly taxing. Fifty-five years after the Blackstone edition, James Kent, Columbia's first law professor, began publishing his comprehensive Commentaries on American Law-which ran to four volumes. In 1858 Abraham Lincoln recommended the reading of five named books (not including Kent's) as "the best way" to enter the learned profession of the law-though he did graciously add that no serious damage would be done if one were to continue reading after having begun practicing. ${ }^{8}$ Sustained and supervised study was certainly not deemed to be prerequisite to becoming learned, for as late as 1900 one could be admitted to the bar in every state without earning a law degree or even an undergraduate college degree. ${ }^{9}$

Columbia's School of Law was launched in 1858, the year in which Mr. Lincoln offered his personal prescription. Columbia's law library, supplemented by a whole shelf of books from the estate of a recently deceased practitioner, went far beyond Lincoln's Big Five. ${ }^{10}$ Years later, when the school moved to more spacious quarters, it still housed its library in a single room, with one long table surrounded by twenty chairs."

From that time onward, lawyers have increasingly exhibited the symptoms of bibliomania. According to one historian of legal literature, in 1810 every judicial opinion preserved in all of America could have been published in eighteen large volumes; a century later the required number of volumes had grown to $8,000 .{ }^{12}$ The typical modern library adds to its collection that many volumes of serials and continuations every year. ${ }^{13}$

Many lawyers successfully resist the temptation to browse in these rich pastures. Being already "learned" ex officio, having derived this status from professional forebears who were recognized as learned long before books proliferated, some are seemingly content to go on in the time-honored way; they allow eccentric brethren to write or compile or even buy books, but they themselves avoid the

7 L. Friedman, A History of American Law 89 (1973). See also Schick v. United States, 195 U.S. 65,69 (1904) (observing that "undoubtedly the framers of the Constitution were familiar with" Blackstone's work).

" L. Friedman, supra note 7, at 525.

Id.

10 Foundation for Research in Legal History, A History of the School of Law, ColumBIA UNIVERSITY $45 \mathrm{n} .9$ (1955).

"Id. at 75.

12 L. Friedman, supra note 7, at 539.

${ }^{13}$ Kavass, Law Libraries of the United States: Development and Growth, 3 INT'L J.L. LiBRARIES 25, 35-36 (1975). 
tedium of reading them in numbers any larger than sufficed for Abraham Lincoln and the framers of the Constitution.

The medical profession, too, achieved the status of being "learned" when becoming learned was not burdensome. A century ago President Eliot of Harvard remarked that in those days anybody could "walk into a medical school from the street," and he added that many who did walk in "could barely read and write."14 In 1910 Columbia required beginning medical students to be high school graduates, though a two-year college requirement had been announced for the future. More than a third of then existing medical schools demanded of their students "little or nothing more than the rudiments or recollection of a common school education."15 The Columbia medical school's library in 1912 contained only 1200 volumes; after two generations that number had grown to about 350,000 . The periodical literature is now so vast that nobody has enough time to read even the abstracts which are meant to provide up-to-date knowledge of what is being published in more extensive versions; the computer supplants the printed page as a means of keeping abreast of current developments.

These animadversions upon the unlearned past of professions indubitably accepted as learned should serve as a reminder that learning is an individual quality. It is not a quality inexorably possessed by everyone who obtains professional status. Many learned persons may exist within a group that is far from learned. Before recorded learning reached its present bulk, respected lawyers and physicians earned high marks for the quality of their thinking even though they had not read books descriptive of other people's thinking; today, some who have crammed themselves full of what passes for learning have neglected to develop the sound judgment without which learning cannot successfully be utilized. Early in this century a famed professor emeritus of Columbia's College of Physicians and Surgeons, speaking at a ceremony in honor of a deceased colleague who had been a professor and practitioner in St. Louis, declared:

The men who worked and taught like him accepted willingly the new additions to diagnosis and practice, but did not substitute them altogether for their old possessions. . . . They had eyes in the tips of their fingers, and their most important instruments of precision were their brains and their practiced

11 A. Flexner, Medical Education in the United States and Canada 12 (1910).

15 Id. at 28-29. Of 155 American and Canadian medical schools in existence in 1910, only sixteen required two or more years of college work to gain entry. 
eyes and ears. May the men who live now never forget that there were great doctors more than fifty years ago.

In truth, possessing wisdom as well as erudition is what entitles a person to be characterized as learned, and a calling becomes a learned profession in more than name only when it is pursued preponderantly by persons who are both well educated and wise.

\section{The Proliferation of Learned Professions or Reasonable Facsimiles Thereof}

In recent decades occupational licensing has grown explosively. One consequence has been a debilitation of the concept of a "profession" and a distortion of the idea that licensing should serve primarily as an instrument of social control to protect the public against unfit or unscrupulous practitioners.

If occupational licensing resulted simply in downgrading the word "profession" or in enlarging the ranks of the "learned," one would have small cause for alarm. After all, the complexities of modern life have created new demands for special training and perceptions. As long ago as 1955 a former Surgeon General of the United States noted that nurses and other health aides are called on to "master a body of knowledge greater in extent and usefulness for the care of the sick than all of the medical knowledge of a century ago. In addition, they have codes of ethics and possess techniques as exact as those of the brain surgeon." 16 So one can understand why what had once been thought of as differences in kind between occupational levels are now often regarded as mere differences in degree; precisely defining the word "profession" is by no means easy. ${ }^{17}$

"W. Gellhorn, supra note 2, at 107 (quoting Dr. Thomas Parran).

17 One authority defines "profession" as

[a] high-status occupation composed of highly trained experts performing a very specialized role in society. A profession has exclusive possession of competence in certain types of knowledge and skills crucial to society and its individual clients. The special intensive education and necessary discipline develops a strong in-group solidarity and exclusiveness. Every profession, on the basis of its monopoly of knowledge and skills and its responsibility for the honor and perpetuation of the profession, tends to feel that it is by itself capable of formulating its ethics and judging the quality of its work. Thus professional groups tend to reject the control of the public or clients they serve. Nevertheless, a profession is, of course, influenced by the public it professes to serve, and it is shaped by the needs of other interest groups and by the demands of other professional organizations.

G. Theodorson \& A. Theodorson, A Modern Dictionary of Soctology 316 (1969). Another authority comments:

Like the aspiration of individuals to be thought virtuous, noble, pious, the aspiration to be accepted as a profession sometimes encourages a good bit of humbug and a steady 
Licensing has done far more than simply gratify the understandable status-longing of semiskilled or specialized workers who, in Professor Merton's words, "want to acquire at least the outer appearance and preferably the inner substance of professional standards, values and education." 18 It has also badly eroded the right to work, one of man's most precious liberties.

Licensing has only infrequently been imposed upon an occupation against its wishes. Unwelcomed licensure has indeed occurred, as when stockbrokers were brought under federal regulation in response to the financial scandals of 1929. In many more instances, however, licensing has been eagerly sought-always on the purported ground that licensure protects the uninformed public against incompetence or dishonesty, but invariably with the consequence that members of the licensed group become protected against competition from newcomers. That restricting access is the real purpose, and not merely a side effect, of many if not most successful campaigns to institute licensing schemes can scarcely be doubted. Licensing, imposed ostensibly to protect the public, almost always impedes only those who desire to enter the occupation or "profes-

flow of false advertising. However, it is one of the tricks that social structures play upon people that the most effective way to appear excellent or hardworking is to bustle about while engaged in seemingly worthwhile tasks, that is, to take real steps in the direction of excellence. As a consequence, the professionalizing occupations are moved to inaugurate programs for obtaining more talented recruits, establishing more rigorous standards for entrance, raising the level of training, putting into force some codes of ethics, or even initiating a university research program. Thereby they feel more justified in their claims and also upgrade the quality of their professional performance. In short, the aspiring occupations, while seeking their own goals of self-aggrandizement, are likely to make genuine moves towards becoming a profession. Thus it is that occupations compete among themselves-just as individuals do-for the available rewards of power, prestige, and money.

W. Goode, The Professionalizing Occupations 98-99. (Columbia University Seminar Report No. 6, 1975). See also W. Goode, Explorations in Sochal Theory 341-82 (1973).

${ }^{18} \mathrm{R}$. Merton, Some Thoughts on the Professions in American Society 7-8 (Brown University Papers No. XXXVII, 1960). The author notes "the spreading tendencies toward specialization in our society," and comments that "many of the traditionally non-professional occupations in business and industry seek to become professionalized. . . . We now hear almost as much about the professionalization of commerce as about the commercialization of the professions." Id. Another author notes:

In the United States, the word profession denotes almost all occupations which require more training than those activities vaguely designated as unskilled or semi-skilled. For general purposes, there is no apparent advantage in distinguishing between a business, a trade, a vocation, and a profession. Such a distinction invariably becomes invidious and is often made without logical basis.

Young, Universities and Cooperation Among Metropolitan Professions, in THE METropous in Modern Life 290 (R. Fisher ed. 1955).

For a richly documented discussion of moves toward professionalization and specialization, see Wallace, supra note 1 . 
sion;" those already in practice remain entrenched without a demonstration of fitness or probity. The self-interested proponents of a new licensing law generally constitute a more effective political force than the citizens who, if aware of the matter at all, have no special interest which moves them to organize in opposition. ${ }^{19}$

The restrictive consequence of licensure is achieved in large part by making entry into the regulated occupation expensive in time or money or both. ${ }^{20}$ In Iowa, for example, a person who aspires to ease the pains of those who suffer from bunions and corns must have graduated from "a school of podiatry approved by the board of podiatry examiners" and must then be examined, according to the statute, "in the subjects of anatomy, chemistry, dermatology, diagnosis, pharmacy and materia medica, pathology, physiology, histology, bacteriology, neurology, . . . foot orthopedics, and others, as prescribed by the board."21 This does indeed sound imposing. One suspects, however, that the verbiage is of more benefit to bunion removers than to bunion sufferers.

In California a license to cut hair can be won only after the completion of a long apprenticeship, graduation from a barber college, and success in an examination that in past years has demanded knowledge of such esoteric things as the chemical composition of the bones and the name of the muscle that is inserted in the hyoid bone. ${ }^{22}$ Illinois purportedly tests a would-be barber's knowledge of, among other things, physiology, electricity, anatomy, and barber history. ${ }^{23}$ Fifty years ago not a single American state required a barber to attend a tuition-demanding "college" for the equivalent of an academic year. Now most of the states insist that new recruits to the hair-cutting profession receive institutionalized instruction in

17 During his tenure as governor of New Jersey, Woodrow Wilson observed, "[M]en who are behind any interest always unite in organization, and the danger in every country is that these special interests will be the only things organized, and that the common interest will be unorganized against them." 2 W. Wirson, Pubuc PAPERS 422 (R. Baker \& W. Dodd eds. 1925). In contemporary political life one perceives an example of President Wilson's thesis in the successful efforts of the "gun lobby" to block gun control legislation, which, according to opinion polls, has widespread (but unorganized) popular approval. According to a 1975 Gallup Poll, $67 \%$ of the American public favors the registration of all firearms, and a like majority of the public has favored such legislation for the past three decades. N.Y. Times, June 5, 1975, $\S 1$, at 20 , col. 4 .

${ }^{20}$ See Maurizi, Occupational Licensing and the Public Interest, $82 \mathrm{~J}$. PoL. Econ. 399, 400 (1974).

${ }^{21}$ IOWA CoDe $\S 149.3$ (1971).

22 Barron, Business and Professional Licensing-California, A Representative Example, 18 StAN. L. Rev. 640, 652-53 (1966).

23 B. Shimberg, B. Esser \& D. Kruger, Occupational Licensing: Practices and Policies 148 (1973). 
bacteriology; histology of the hair, skin, nails, muscles, and nerves; diseases of the skin, hair, glands, and nails; and other matters about which one may venture to guess few barbers are consulted. Most of the barber examining boards apparently draw their tests from a small booklet published by Milady Publishing Company, which also produces the textbook most barber colleges use because that single volume apparently reveals everything their students need to know to pass the examination. ${ }^{24}$ Plainly, a barber need not overburden his mind with scientific or theoretical profundities. The costly and time-consuming acquisition of artificial learning in a pseudo profession nevertheless blocks an occupational choice that might otherwise be available to the impecunious.

\section{Occupational Licensing and Competition}

\section{A. Irrelevancies as Barriers to Competition}

Barbering has been used as a horrible example, but irrelevancies are by no means confined to any one of the new "professions." Years ago a Wisconsin legislator, after examining some of that state's occupational requirements, exclaimed sadly that as a practical matter, her child could no longer aspire to become a watchmaker, but fortunately could still qualify to seek the presidency of the United States. ${ }^{25}$ In some states virtually the only "profession" open to a once-convicted felon is that of burglar; he is barred from other activities because he is presumed to be a person of bad moral character, regardless of the nature of the felony or its relevance to his intended occupation. ${ }^{26}$ Until the courts finally called a halt,

24 Id. at 146. A New York cosmetology school boasts that $99.9 \%$ of its graduates pass the state examination. The school's head "explained that throughout the year, students are drilled on questions from a review book published by Keystone Press. This particular book, he stated, contains about $90 \%$ of the questions that are likely to appear on the examination." Id. at 150 .

${ }^{25}$ Doyle, The Fence-Me-In Laws, 205 Harper's Magazine 89 (1952).

21 For a discussion of this kind of permanent disqualification, see W. GellHoRN, supra note 2, at 128-29. Fortunately, some encouraging signs of change can be detected. For example, a recent New York statute forbids denial of a license because of a previous conviction in the absence of a "direct relationship between one or more of the previous criminal offenses and the specific license or employment sought" or "an unreasonable risk to property . . . or the general public." 1976 N.Y. Laws, ch. 931 . See also Butts v. Nichols, 381 F. Supp. 573 (S.D. Iowa 1974) (holding unconstitutional a statute which barred felons from all civil service employment without taking into account the nature of the job or the felony). For more extended discussion, see American Bar Ass'n, Removing Offender Employment Restrictions (2d ed. 1973); H. Banks, S. Shestakofsky \& G. Carson, Civil Disabilities of Ex-Offenders 11-33 (1974) (Center for the Study of Legal Manpower Disabilities, New York); Meltsner, Caplan \& Lane, An Act to Promote the Rehabilitation of Criminal Offenders in the State of New York, 24 Syracuse L. Rev. 885 (1973); Note, New Approaches to the Civil Disabilities 
becoming a master plumber in Illinois took just a bit longer than becoming a Fellow of the American College of Surgeons. ${ }^{27}$

Some restrictions on occupational choice are blatant absurdities. For example, Georgia insists that those who seek to be commercial photographers must pass with flying colors a Wasserman test for syphilis. ${ }^{28}$ At one time the Indiana Athletic Commission insisted that boxers and wrestlers take a loyalty oath before being allowed to enter the ring. ${ }^{29}$ Silliness like this is probably not motivated by anything so rational as a desire to discourage competition.

More often, however, the statutory constraints have had truly exclusionary intent and effect. These constraints include requirements that licensees be citizens or residents of a locality. Although these restrictions are probably unconstitutional, ${ }^{30}$ they are enforced until challenged. Some states insist that only an American citizen can qualify to become, for instance, a pharmacist, chiropodist, tree surgeon, embalmer, bill collector, or osteopath-evidencing a type of xenophobia which reached a fever pitch in state legislatures in the late 1930s when European refugees began arriving in large numbers during a time of job scarcity. ${ }^{31}$ Other laws provide that, regardless

of Ex-Offenders, 64 Ky. L.J. 382 (1976); Special Project-The Collateral Consequences of a Criminal Conviction, 23 VANd. L. Rev. 929, 1001-18, 1155-68 (1970).

${ }^{27}$ People v. Brown, 407 Ill. 565, 95 N.E.2d 888 (1951). See also Note, Restriction of Freedom of Entry into the Building Trades, 38 Iowa L. REv. 556, 559, 561 (1953).

2* Ga. CODE ANN. § 84-2315 (1975).

20 R. Brown, Loyalty and Security 118 (1958).

${ }^{30}$ The constitutionality of citizenship requirements is too complex a matter to analyze, or even summarize, in a footnote. Modern courts generally look askance at statutes which make citizenship a prerequisite of doing or obtaining something with little functional relationship to citizen or alien status. See, e.g., Examining Bd. of Eng'rs., Archs., \& Surveyors v. Florez de Otero, $96 \mathrm{~S}$. Ct. 2264 (1976) (license to practice as civil engineer could not constitutionally be withheld because of applicant's noncitizenship); Hampton v. Mow Sun Wong, 96 S. Ct. 1895 (1976) (barring aliens from federal competitive civil service positions violates due process in the absence of an adequate justification); In re Griffiths, 413 U.S. 717 (1973) (admission to the Connecticut bar may not be made to hinge on citizenship); Sugarman y. Dougal, 413 U.S. 634 (1973) (citizenship may not be made a prerequisite of eligibility for civil service appointment in New York).

"11 Moore, The Purpose of Licensing, 4 J. LAw \& Econ. 93, 97 (1961). The manifest irrationality of the citizenship requirement is emphasized by its inconsistent application. In Texas, the law says that only an American citizen may be a barber, but any qualified person may be a cosmetologist; Florida's law says exactly the opposite. In some New York cities, only U.S. citizens may be plumbers, but noncitizens may install oil burning equipment. $B$. ShIMBERG, B. EssER \& D. KRUGER, supra note 20, at 85. The matter has not escaped scholarly criticism abroad. See, e.g., Altug, The Right to Work of Aliens in the United States, 18 ANNALES DE LA FACULTE DE DROIT D'INSTANBul 269 (1962). The author, a well-known Turkish law professor, concludes that despite steady improvement in the recognition of aliens' rights, their legal status has been affected by statutes "inspired by too much nationalistic feeling and economic competition." These statutes "contrast with American ideals of tolerance, equality and hospitality" which are esteemed throughout the world. Id. at 317. 
of national citizenship, a licensee must have been a resident of the license-issuing state for a substantial period of time-although the relationship between prior residence and occupational qualifications may be undiscoverable, as in the case of optometrists, accountants, masseurs, and dentists. ${ }^{32}$ One would suppose that lenses are ground and teeth are cleaned in essentially the same manner in different states, but the statutes pretend that one must have lived within the license-issuing state in order to understand its citizenry's needs. Occupational licenses have also been conditioned upon residency in political subdivisions smaller than a state. Twenty-eight states provide for the licensing of plumbers, but in most of these states the plumbers have managed to prevent licensing on a statewide basis. Instead, licenses are issued by the cities, which impose municipal residence requirements aimed at excluding "outsiders" from the local job market. ${ }^{33}$ Some state laws authorize counties and cities to say who may become an auctioneer, plumber, fortune teller, lawn-sprinkler installer, and stationary engineer, among other "professions" for which residence is made a sine qua non..$^{34}$ Outsiders, no matter how highly skilled or experienced, are barred by reason of not being able to claim a narrowly localized experience.

Americans have traditionally thought themselves free to pursue happiness wherever it might be found. Mobility-lateral as well as

${ }^{32}$ Note, Residence Requirements after Shapiro v. Thompson, 70 CoLuM. L. Rev. 134, 148 52 (1970). In Shapiro v. Thompson, 394 U.S. 618 (1969), the Supreme Court struck down statutes which made prior residence a condition of eligibility for public welfare benefits. The law of residence requirements does, however, have convolutions. In Dunn v. Blumstein, 405 U.S. 330 (1972), the Court held that eligibility to vote could not be postponed by durational residency requirements functionally unrelated to the prevention of vote fraud. In Memorial Hosp. v. Maricopa County, 415 U.S. 250 (1974), the Court held unconstitutional a statutory requirement of a year's residence within the state before a patient could become eligible for treatment in a public hospital at the expense of the local government. On the other hand, in Sosna v. Iowa, 419 U.S. 393 (1975), the Court held that a state need not open its courts to petitioners for divorce, until "residence" had been firmly established. See Keeffe, Sticking It Out For a Year: Iowa's Residency Requirement, 62 A.B.A.J. 922 (1976). See generally Note, Durational Residence Requirements from Shapiro through Sosna: The Right to Travel Takes a New Turn, 50 N.Y.U.L. REv. 622 (1975). And in McCarthy v. Philadelphia Civil Serv. Comm'n, 96 S. Ct. 1154, 1155 (1976), the Court upheld as a "bona fide continuing residence requirement" a rule that employees of a municipal fire department must be residents of the city. See Detroit Police Officers Ass'n v. City of Detroit, 405 U.S. 950 (1972), dismissing appeal from 385 Mich. 519, 190 N.W.2d 97 (1971); Annot., 65 A.L.R.3d 1048 (1975). See also Starns v. Malkerson, 326 F. Supp. 234 (D. Minn. 1970), aff'd, 401 U.S. 985 (1971) (sustaining a one-year residency requirement as a prerequisite to qualifying for tuition benefits in a state university); Annot., 37 L. Ed. 2d 1056 (1973).

3 B. Shimberg, B. Esser \& D. Kruger, supra note 23, at 69.

* See, e.g., Iowa Code $\$ \$ 546.1,368.6,368.8,368.45$ (1971). See also B. Shimberg, B. Esser \& D. Kruger, supra note 23, at 67, 82; Note, Occupational Licensing: An Argument for Asserting State Control, 44 Notre Dame Law. 104, 109-12 (1968). 
upward and sometimes downward-has been a characteristic of our society, and most of us think it has made for a healthier country, one in which parochialism has yielded to the inflow of new populations, new ideas, new techniques. Local licensure tends in the opposite direction, toward enclosure within fixed boundaries. Requirements unrelated to suitability and proficiency probably will not withstand judicial scrutiny, but until a frustrated applicant chooses to take a case to court-or until conscientious legislators repeal obnoxiously discriminatory statutes-the bad laws remain as threats to occupational freedom.

All reasonably sophisticated persons know that a well-knit special interest group is likely to prevail over an amorphous "public" whose members are dispersed and, as individuals, are not in sharp conflict with the organized interest. ${ }^{35}$ Of course many special interests perceive themselves as nurturers of the public interest rather than as self-seekers. The line between the common weal and one's own is not always easily drawn. But occupational licensing has typically brought higher status for the producer of services at the price of higher costs to the consumer; ${ }^{38}$ it has reduced competition; ${ }^{37}$ it has narrowed opportunity for aspiring youth by increasing the costs of entry into a desired occupational career; ${ }^{38}$ it has artificially seg-

${ }^{15}$ See W. WILson, supra note 19. Professor Milton Friedman has observed:

The declaration by a large number of different state legislatures that barbers must be approved by a committee of other barbers is hardly persuasive evidence that there is in fact a public interest in having such legislation. Surely the explanation is different; it is that a producer group tends to be more concentrated politically than a consumer group. . . . [P]eople in the same trade, like barbers or physicians, all have an intense interest in the specific problems of this trade and are willing to devote considerable energy to doing something about them. On the other hand, those of us who use barbers at all, get barbered infrequently and spend only a minor fraction of our income in barber shops. Our interest is casual. Hardly any of us are willing to devote much time going to the legislature in order to testify against the iniquity of restricting the practice of barbering. . . . The public interest is widely dispersed. In consequence, in the absence of any general arrangements to offset the pressure of special interests, producer groups will invariably have a much stronger influence on legislative action and the powers that be than will the diverse, widely spread consumer interest. Indeed, from this point of view, the puzzle is not why we have so many silly licensure laws, but why we don't have far more. The puzzle is how we ever succeeded in getting the relative freedom from govern. ment controls over the productive activities of individuals that we have had and still have in this country, and other countries have had as well.

M. Friedman, Capitalism and Freedom 143 (1962). See also Maurizi supra note 16, at 399.

is Maurizi, supra note 16 , at 399-403.

${ }^{77}$ See Office of Policy Planning and Evaluation, FTC, 1976 Federal Trade Commission Budget Overview, 32 Antitrust \& Trade Reg. Rep. (BNA) A1, D1-D2 (Dec. 24, 1974). See also J. Sims, supra note 3.

${ }^{3 x}$ Maurizi notes that often the examination process is made unduly burdensome, as, for example, by conducting examinations at only one city within a large state. 
mented skills so that needed services, like health care, are increasingly difficult to supply economically; ${ }^{39}$ it has fostered the cynical view that unethical practices will prevail unless those entrenched in a profession are assured of high incomes; ${ }^{40}$ and it has caused a proliferation of official administrative bodies, most of them staffed by persons drawn from and devoted to furthering the interests of the

By sometimes requiring applicants to bring all their own tools and equipment to the examining station, the agency adds a considerable cost to some applicants. Some cosmetologists, for example, must bring their own human model; some truck drivers must bring their own trucks. Furthermore, in some occupations knowledge about what applicants must do to pass the examination is difficult to obtain; plumbers' examinations are so unpredictable that applicants often must take the exam once (figuring to fail it) in order to find out what it is like.

Maurizi, supra note 16 , at 400 n.1.

" [Licensing laws have become] major obstacles to the expansion of the functions of health personnel and to the effectuation of innovations or developments in the uses of new or existing personnel. . . .

Fifteen different [health-care] professions require a license to practice and are directly affected by the licensure laws. . . .

The increasing number of licensed health groups leads to the creation of overlapping areas of practice artificially separated by the structuring of health personnel into narrow functions. The increases in the number of licensed categories make it increasingly difficult to define who can best provide given types of care and treatment. . . .

[L]icensure, originally designed to protect the public, has been to a considerable degree transformed into a means of professional control leading to the protection of professional interests.

Contemporary Studies Project: Regulation of Health Personnel in Iowa - A Distortion of the

Public Interest, 57 Iowa L. REv. 1006, 1007, 1013, 1014 (1972) (footnotes omitted).

[Hospitals] must have some freedom to use personnel in flexible work arrangements. Job changes, job enlargement, and job upgrading all require flexibility in manpower education and use.

. . . The shortages of licensed personnel, as defined by the law, encourage violations of the law by both employers and employees. In fact, strict compliance with the law would close many hospitals.

Egelston \& Kinser, Licensure of Hospital Personnel, Hospitals, Nov. 16, 1970, at 35, 37, quoted in B. ShImBerg, B. EsSER \& D. KRUGer, supra note 23, at 16-17.

10 Professor Friedman notes:

[Members of the medical profession do not] deliberately go out of their way to limit entry in order to raise their own incomes. That is not the way it works. Even when such people explicitly comment on the desirability of limiting numbers to raise incomes they will always justify the policy on the grounds that if "too" many people are let in, this will lower their incomes so that they will be driven to resort to unethical practices in order to earn a "proper" income. The only way, they argue, in which ethical practices can be maintained is by keeping people at a standard of income which is adequate to the merits and needs of the medical profession. I must confess that this has always seemed to me objectionable on both ethical and factual grounds. It is extraordinary that leaders of medicine should proclaim publicly that they and their colleagues must be paid to be ethical. And if it were so, I doubt that the price would have any limit.

M. Friedman, supra note 35, at 152. 


\section{licensed occupations themselves. ${ }^{41}$}

Moreover-and this is a point largely unnoticed-members of ethnic minorities are systematically discouraged from becoming licensees by irrelevant requirements. Licensing tests are often administered solely in English, so that Spanish-speaking citizens and foreign-born residents encounter special difficulty. ${ }^{42}$ In some instances, indeed, written tests may be altogether inapposite means of determining whether an applicant possesses a requisite degree of skill. ${ }^{43}$ Many economically deprived young people cannot easily meet the qualifications demanded of applicants, such as paying tuition to pseudo-professional schools or undergoing needlessly prolonged periods of apprenticeship. Recent years have seen hard won progress in overcoming racial discrimination in private employment. Discrimination, as the courts have found, has been strongly reinforced by ostensibly objective tests which are actually unrelated to successful job performance, and employers have been ordered to abandon this kind of testing. ${ }^{44}$ The time is ripe for those who care

\footnotetext{
" One study notes:

In forty-four of the American states, for example, members of the state boards of nursing are chosen solely from nominees of the state nursing associations. It is not thought proper to select those who regulate public utilities from nominees of the utility companies or an insurance commissioner from nominees of the insurance companies. . . .

It is typical for a state to have more than 150 statutorily established boards, commissions, agencies, councils and committees. It is futile to expect a Governor to be able to coordinate the activities of such an array of units.
}

Holmer, The Role and Functioning of State Licensing Agencies, 40 State Gov't 34, 35-36 (1967). On April 1, 1976, New York became the proud possessor of two new professions, subject to nominally official regulation. The State Board for Occupational Therapists consists of seven therapists, a hospital administrator, a physician, and one "public representative." The State Board for Speech Pathology and Audiology consists of three audiologists and four speech therapists. N.Y. Educ. LAw §§ 7901-03, 8201-05 (McKinney Supp. 1975). See also W. GELlhorn, supra note 2, at 140-44; J. LIEBERMan, The TYRANNY OF THE ExPERTs 252-54 (1970). For a somewhat more sympathetic analysis of licensing boards, see Liebmann, Delegation to Private Parties in American Constitutional Law, 50 IND. L.J. 650, 704-09 (1975).

12 K. Greene, supra note 2, at 6.

43 For example, in 1937, North Carolina enacted a statute barring anyone other than a licensed tile layer from engaging in the business of laying ceramic tiles. Two decades later, in the words of one commentator, the "tile laying establishment was fatally hit by a semiliterate, unlicensed youth" who had flunked the licensing examination. J. LieBERMaN, supra note 41, at 11. In Roller v. Allen, 245 N.C. 516,96 S.E.2d 851 (1957), the licensing board was restrained from enforcing the law. The court noted the applicant's poor spelling and defective syntax on the written exam, but found his lack of command of written English to bear no relevance to his skill as a tile layer. "Successful tile contracting consists in doing the work rather than describing it in a written examination. In all probability the average worker could learn to do acceptable tile work as quickly as he can learn to describe it on paper." Id. at 522,96 S.E.2d at 857.

"see, e.g., Griggs v. Duke Power Co., 401 U.S. 424 (1971); Duhon v. Goodyear Tire \& Rubber Co., 494 F.2d 817 (5th Cir. 1974). 
about social justice to attack licensing regulations which, with all the force of government, authorize similarly obnoxious entry examinations and thus achieve discrimination behind the facade of protecting the public.

\section{B. Limits of Antitrust Remedies}

Present antitrust laws may be ineffective in overcoming the significant anticompetitive consequences of laws that make access to an occupation burdensome and impose restraints upon those who have managed to gain a license. In 1943 the Supreme Court held that the antitrust statutes are aimed at private, not state, action, and ruled that a California statute constricting the competitive marketing of raisins immunized behavior the antitrust laws would otherwise have forbidden. ${ }^{45}$ Although the force of the case has diminished because courts have sometimes been inattentive to its doctrine, Professor Verkuil has argued with great effectiveness that it deserves to be respected.

Although presumably disdainful of substantive due process, the federal courts have seized upon another approach to oversee state economic regulation. Increasingly, the challenge to occupational licensing and price fixing by state regulatory bodies has come in the form of application of the antitrust laws to the offensive conduct. . . . One tends initially to applaud this aggressive antitrust posture as a welcome corrective to a runaway regulatory problem. Upon further reflection, however, those who oppose substantive economic review of state activity under the due process clause should doubt the advisability of engaging in antitrust review of that same activity, and for precisely the same reasons. . . . The ultimate consequences of heedless application of the antitrust laws to state regulatory schemes could well be a crisis in federalism not dissimilar to that created by the Supreme Court in the 1930's. . . .

[Parker $v$. Brown] vindicated the overriding principle of the 'constitutional revolution of 1937' that the states should be free to make their own economic decisions, whether or not they comport with the economic principles in vogue with the federal judiciary. ${ }^{46}$

4 Parker v. Brown, 317 U.S. 341, 350-52 (1943).

"Verkuil, State Action, Due Process and Antitrust: Reflections on Parker v. Broun. 75 Colum. L. REv. 328, 329-30, 334 (1975) (footnotes omitted). See also Verkuil, Preemption of State Law by the Federal Trade Commission, 1976 DuKE L.J. 225 (1976). 
Somewhat similarly, Professor Handler concludes that the doctrine of Parker $v$. Brown is "integral to our federalism." He favors "endowing the states with broad latitude in their economic experiments," turning to the states

as the forum for the correction of the mischief that inevitably arises under any system of social control. This may not lead to the best of all possible worlds but neither will the various proposals for the curtailment of Parker .... [T] [Te preservation of our federalism overrides whatever benefits might flow from extending the reach of antitrust by limiting the ambit of the state action defense..$^{47}$

Even a reinvigoration of the state action defense should not, however, bar the use of antitrust laws against restrictive practices adopted voluntarily within a licensed occupation. The antitrust laws may not reach an anticompetitive economic policy embedded in a state's statute, but they can and do reach anticompetitive policy choices made by licensees, perhaps without a state's opposition and yet not by its direction. A state must command, not merely permit, a restraint of trade in order to immunize it against federal antitrust laws.

This lesson was taught the legal profession in 1975, when the Supreme Court in Goldfarb v. Virginia State Bar ${ }^{48}$ held that a bar association's minimum fee schedule violated the Sherman Act's prohibition of combinations in restraint of trade. ${ }^{99}$ How often the lesson may have to be taught to others remains to be seen. The occupational licensing statutes to which this article has been addressed tend to reduce competition, but they rarely acknowledge this to be their purpose-and even less often do they direct licensees to submit to explicitly anticompetitive controls for monopolistic purposes. The restrictive practices of licensed groups are usually designed within the groups, rather than imposed on them from the

17 Handler, The Current Attacks on the Parker v. Brown State Action Doctrine, 76 Colum. L. Rev. 1, 20 (1976). Professor Handler comments on "Professor Verkuil's excellent analysis of the relationship between the substantive due process cases and the Parker doctrine-a relationship which I believe he was the first to perceive. . . . His unique piece of scholarship should cause those who advocate a headlong and wholesale retreat from Parker to stop, look, and listen before breaching the basic tenets of the federalism upon which rests our constitutional form of government." Id. at 7 n.35.

t* 421 U.S. 773, 791 (1975); see Comment, 7 Loy. U.L.J. 254 (1976).

19 See also Glenn, Minimum Fee Schedules for Attorneys as Constituting Violation of Sherman Act, 44 L. Ev. 2D 818 (1976). For the most recent interpretation of the application of the Parker v. Brown doctrine, see Cantor v. Detroit Edison Co., 96 S. Ct. 3110 (1976). 
outside. To the extent that this is so, Parker $v$. Brown $n^{50}$ gives no protection against the antitrust laws, for the Supreme Court has differentiated between state action and private action wearing a mask. ${ }^{51}$

\section{Lawyers, Specialization, and Continuing Legal Education}

The prudence as well as the legality of recent proposals to categorize lawyers and to require their periodic participation in formal educational programs may be questioned. The specialization issue is likely to prove difficult. As a result of the Goldfarb case and controversy concerning other groups' restraints upon the advertising of services and costs, ${ }^{52}$ the legal profession has cautiously modified its traditional insistence that speaking about oneself in a tone louder than a whisper is unethical. ${ }^{53}$ In 1976 for the first time the American Bar Association voted that a lawyer should be permitted to indicate "in dignified form" in professional announcements and in the yellow pages of telephone directories his preferred areas of practice and his educational background. ${ }^{54}$ The Association frowns

so 317 U.S. 341 (1943).

31 Id. at 351; Comment, Occupational Licensing: An Antitrust Analysis, 41 Mo. L. Rev. 66, $72-76$ (1976).

32 See, e.g., Virginia State Bd. of Pharmacy v. Virginia Citizens Consumers Council, 96 S. Ct. 1817 (1976); Benham \& Benham, Regulating Through the Professions: A Perspective on Information Control, $18 \mathrm{~J}$. LAw \& EcoN. 421 (1975); Benham, The Effect of Advertising on the Price of Eyeglasses, 15 J. LAw \& Econ. 337 (1972). The Federal Trade Commission has announced an investigation of practices by private optometrist associations which restrict price information available to the public. Federal antitrust proceedings have been initiated against associations of accountants, anesthesiologists, architects, physicians, and realtors, among others, because of their controls over fees and advertising. Kohlmeier, Price Fixing in the Professions, N.Y. Times, April 18, 1976, § 3, at 3, col. 1.

${ }_{53}$ The unethicality of advertising has long been an article of faith among professionals, and the courts have generally shared this faith. See, e.g., Semler v. Oregon State Bd. of Dental Examiners, 294 U.S. 608 (1935) (involving prohibition of dentists' advertising). In that case Chief Justice Hughes remarked, "What is generally called the 'ethics' of the profession is but the consensus of expert opinions as to the necessity of such standards." Id. at 612. But see Virginia State Bd. of Pharmacy v. Virginia Citizens Consumer Council, 96 S. Ct. 1817, 1832 n.25 (1976). See also In re Cohen, 216 Mass. 484, 159 N.E. 495 (1928); Comment, Advertisement and the Bar, 1 J. Legal Profession 179 (1976).

st ABA Code of Professional Responsibility, Disciplinary Rule 2-102 (A)(5)-(6); see House Broadens Code's "Publicity in General" Rules at Midyear Meeting in Philadelphia, 62 A.B.A.J. 470 (1976). The ABA still frowns upon resort to advertising in newspapers or other mass media to inform the public about a lawyer's eagerness (and supposed ability) to render service. ABA Code of Professional Responsibility, Disciplinary Rule 2-101. Even the mild $A B A$ "reform" was deemed to be unacceptable by the Virginia Supreme Court, which refused to modify its rules to conform to the new standards. 44 U.S.L.W. 2508 (May 4, 1976).

As this article was being prepared for publication, the Supreme Court agreed to hear a case involving both antitrust and first amendment challenges to state restrictions on lawyers' 
upon a lawyer's identifying himself as a "specialist" unless he has met the requirements of a state program of certification. ${ }^{55}$

Whether, when, and how lawyers should be allowed to assert that they have special qualifications are still unresolved questions. Genuinely high-minded and disinterested persons have urged that formal identification of specialists is needed to protect uninformed laymen against incompetent, inefficient, or inadequately experienced lawyers who may disserve their clients' best interests. They think that lawyers should emulate doctors in drawing more distinct lines than now separate specialists and general practitioners.

Thirty-three varieties of medical specialists can now be recognized because they have achieved "board certification." 56 A licensed physician who wishes to be formally identified as equipped to practice in one of these thirty-three areas of specialization must complete additional training and survive an examination by the certifying agency, composed of persons already certified. To be sure, certification is not a prerequisite of a generalist's performing a specialist's task. Many hospitals, however, make their facilities available only to those who possess board certification, and thus the incentive to gain board approval has been strong in the medical profession. ${ }^{57}$

Everyone within the legal profession knows that specialization exists. Attorneys are frequently and familiarly identified, by their colleagues in the profession and by themselves, as tax lawyers or commercial lawyers or corporate lawyers or labor lawyers or communications lawyers or criminal lawyers or divorce lawyers-the list could be elongated far beyond the thirty-three specialists the doctors have proclaimed. A question of lively interest to the profession

advertising. Bates v. State Bar of Arizona, 555 P.2d 640 (Ariz.), prob. juris. noted, 45 U.S.L.W. 3203 (U.S. Oct. 4, 1976).

s A gentle critic has pointed out in an American Bar Association publication that even in legal directories (which, typically, are little known by laymen) lawyers are not allowed to provide very much information about themselves.

For example, a lawyer cannot indicate his area of expertise unless he qualifies as a specialist under state standards; he cannot mention how many cases he has handled of a particular type or for how many years; he may say he has an LL.M., but he may not add the words "in taxation"; he may not indicate experience by reference to a specialized tribunal, such as "practice before the ICC"; he may not ever say "former chairman of the ABA Indian Affairs Committee."

Hobbs, Lawyer Advertising: A Modest Proposal, Alternatives: Legal Services and the Public, February, 1976, at 3-4. See also Smith, Making the Availability of Legal Services Better Known, 62 A.B.A.J. 855 (1976).

so Mindes, Lawyer Specialty Certification: The Monopoly Game, 61 A.B.A.J. 42, 43 (1975).

${ }_{77}$ See Rayack, Restrictive Practices of Organized Medicine, 13 Antitrust BuLl. 659, 70102 (1968). See also Mindes, supra note 56, at 43. 
is whether the de facto specialization of today, acquired freely either by explicit design or simply through the vicissitudes of practice, should in the future be attested through certification. Tension exists between the laudable desire to ensure the efficient rendition of professional services to clients and the not necessarily intended likelihood that certification will reduce competition among lawyers, discourage well qualified but uncertified persons from performing functions within the zone of a "specialization," and thus increase the costliness of legal services. ${ }^{58}$ Were no lawyer permitted to identify himself as equipped to engage in a special type of practice until he had been certified, exclusivity would be powerfully stimulated. ${ }^{59}$ This seems the probable outcome if formal certification spreads widely.

The legal profession must take great care not to emulate the many occupational groups that have managed to convert licensure from a sharp weapon of public defense into a blunt instrument of self-enrichment. Perhaps instead of continuing toward specialist certification, the bar should permit each member to inform the public, if the member chooses, about the kinds of legal service he or she is prepared to render. ${ }^{60}$ Misrepresentation of qualifications or demonstrated incompetence should of course be deemed cause for disciplinary action. ${ }^{61}$ Proceedings aimed at individual malefactors

5x For an unflattering estimate of what certification is likely to accomplish for consumers of services, see J. LieBERMaN, supra note 36, at 248-51. Professor Friedman, proceeding on the assumption that specialist certification would not legally bar uncertified persons from practicing within an occupation, writes:

[I]f, in certifying newcomers, members of the trade impose unnecessarily stringent requirements and reduce the number of practitioners too much, the price differential between certified and non-certified will become sufficiently large to induce the public to use non-certified practitioners. In technical terms, the elasticity of demand for the services of certified practitioners will be fairly large, and the limits within which they can exploit the rest of the public by taking advantage of their special position will be rather narrow.

M. FRIEDMAN, supra note 35 , at 149 .

3" For discussion of this possibility, see Tyler, Goldfarb $v$. Virginia State Bar: The Professions are Subject to the Sherman Act, 41 Mo. L. Rev. 1, 30-31 (1976). See also Mindes, supra note 56. But see also Brink, Let's Take Specialization Apart, 62 A.B.A.J. 191 (1976).

* One commentator recommends:

1. Specialty. At present a lawyer can only state in a directory that he concentrates or limits his practice to certain fields. This should be broadened to permit one to say what kind of case he will accept, as is now common in lawyer referral programs.

2. Qualifications. The present limitations should be broadened at least to let lawyers say how long they have been practicing in the field, and the bar associations should be urged to develop a fuller system for permitting lawyers to state their experience and other qualifications.

Hobbs, supra note 55, at 5 .

"See W. Gellhorn, supra note 2, at 149-50. 
or bumblers might more meaningfully protect the public than would the creation of clusters of self-anointed specialists. In the past lawyers have been backward about taking steps against unworthy members of their own profession. This seems to be characteristic of professional people in general; they criticize one another's shortcomings in private, but are rather resistant to disciplining the unfit and the unscrupulous in public proceedings. If, however, the professions are to continue to enjoy the autonomy they so highly prize, they will have to accept more fully the responsibility implicit in a privileged status.

The advocacy of mandatory continuing legal education, sometimes linked with proposals concerning specialist certification, has also become clamorous. Four states have already approved mandatory systems intended (as their proponents say) to maintain high levels of professional competence; similar plans are said to be under serious consideration in more than half the states. ${ }^{62} \mathrm{~A}$ common feature of the plans is that all licensed lawyers must annually enroll for a stated number of hours in formal course work, in programs approved by a state supervisory body.

The efficacy of this kind of compulsory education is dubious. Advocates of forced schooling have at times ignored the expense involved, have overlooked the reality that sitting in lecture halls for, say, fifteen hours a year may not be a highly productive mental exercise, and have made assumptions about the cause and cure of professional inadequacies without verifying them by empirical studies. Moreover, mandatory continuing legal education involves large hidden social costs. The Executive Director of the American Law Institute-American Bar Association Committee on Continuing Professional Education has estimated that

[a] state with 10,000 lawyers would require, at a minimum, $\$ 10$ an hour for any quality program. If 15 hours a year are the standard, as in Minnesota and Iowa, the total annual cost to the sponsoring agencies amounts to $\$ 1,500,000$, and this is probably an underestimation. Registration fees would need to recover, at a minimum, this sum. The cost to each lawyer would be greater than his tuition, however, since it would include time away from the office and, in some instances, travel and lodging. These factors escalate the cost projections to substantially higher limits. While initially these costs would be

82 See Wolkin, On Improving the Quality of Lawyering, 50 ST. JoHN's L. Rev. 523 (1976) (a treasure-trove of information concerning continuing legal education proposals). 
borne by the lawyer, they ultimately would be passed on to the public. ${ }^{63}$

Obviously, costliness does not show worthlessness. Still, lawyers should be closely attentive to the experience of other licensees lest they end by disserving the public interest they purportedly safeguard.

\section{CoNCLUSION}

If men were angels, as has been remarked, external controls over their conduct would be superfluous. Since the most recent census fails to disclose a significant increase in the angelic population, I do not join those who advocate ending occupational licensing altogether. Painful economic experiences might ultimately lead consumers of services to locate the most efficient, most trustworthy suppliers. Meanwhile, however, many persons would suffer avoidable wounds to person or purse. The anonymity of a largely urbanized American society prevents the kind of informed choice which may have been possible when clients, patients, and customers could rely with reasonable confidence upon neighbors' opinions of professionals and tradesmen. For that reason I accept the view that in some occupations some kind of quality control may be needed to protect the uninformed against blatant incompetents, wily charlatans, and persons whose past delinquencies suggest the probability of future corrupt conduct.

Everything is, however, a matter of degree. I am comforted by the thought that surgeons and structural engineers must pass scrutiny by somebody more knowledgeable than I am or am likely to become about their qualifications. On the other hand, I think it absurd to set up elaborate mechanisms as precautions against my being dissatisfied with the way my hair has been cut, my toenails trimmed, my muscles kneaded, my hearing aid fitted, or my drains unclogged. Only the credulous can conclude that licensure is in the main intended to protect the public rather than those who have been licensed or, perhaps in some instances, those who do the licensing. ${ }^{64}$

13 Id. at 542 (footnotes omitted). See also 62 A.B.A.J. 210 (1976).

" In North Carolina, for example, a recent legislative inquiry reportedly disclosed that thirty-two licensing boards had developed "questionable practices." The three women who constitute the State Board of Cosmetic Art Examiners paid themselves salaries from $\$ 8,277$ to $\$ 8,913$, plus expenses, for meeting "every month for about three days." The Governor's appointments secretary recalled that some 150 barbers lobbied to be appointed to fill a vacancy in the Board of Barber Examiners. He was not surprised, since the examiners are 
To say that licensing has been abused and overused is not to say that prophylactic administration should be abandoned. I do not advocate reviving the doctrine of caveat emptor, nor do I, as a realist, suppose for a minute that customers and clients who have been ill served can be made whole by lawsuits against their miscreant servitors. Litigation is too unwieldly to meet the needs of those who have suffered minor injuries. What are needed are measures that will provide protection against those demonstrably deficient in capability or integrity without in the process creating artificial limitations upon career choices, work opportunities, and stimuli to provide superior service at lesser cost. Among these protective measures are permissive certification and mandatory registration.

Permissive certification may be suitable when a program of prior training or a demonstration of an objectively measurable degree of skill can be regarded as a genuine precondition of a person's claiming an occupational status. For example, some state laws provide that before a person identifies himself as an "architect," he must have been certified as one who deserves that title because he has given proof of his education and capability. These laws do not, however, bar others from engaging in the work architects do; those who are uncertified may not call themselves "architects," but they may do work of an architectural nature without risking prosecution for engaging in the "unauthorized practice" of a licensed occupation. Certification of this kind permits pertinently defined expectations, so that the consuming public can differentiate between a selfstyled expert and a person whose qualifications have been passed on by a state authority. Yet, unlike licensure, this control mechanism does not wholly withdraw occupational opportunity from persons who, though unable to meet all the requirements of certification (for example, formal education), may be competent.

A far more comprehensive regulatory device is the simple registration of anyone who desires to receive a particular occupational license, with the automatic issuance of the license upon registration. Engaging in the occupation without a license, or obtaining it by misrepresentation, would be made a serious offense, in order to stimulate prompt and accurate registration. An appropriate state agency, not linked with an occupational group, would be created to receive complaints against licensees, investigate them, and, if objectionable conduct is found, initiate proceedings looking toward revo-

paid "about $\$ 14,000$ per year, their expenses are paid (for traveling around the state to inspect barber shops) and they set their own schedules." Cullen, N.C. Occupational Licensing Boards Facing Close Look, Durham (N.C.) Sun, Feb. 19, 1974, § A, at 5, col. 1. 
cation, suspension, or other appropriate discipline by a court or a special tribunal. ${ }^{65}$

A plan of this nature would, I believe, end the present abuse of licensure that serves selfish interests by constricting occupational freedom. It would recapture the public power now delegated to multiple licensing boards whose members are drawn from and owe allegiance to the occupations they supposedly regulate in the public interest. It would require that licensees be subject to stern discipline, but only after carefully formulated charges, fair hearings, and impartial determinations, untainted by suspicion that the determiners' self-interest has influenced their judgment. ${ }^{66}$ It would take away the eligibility of those whose occupational unworthiness could be demonstrated, but would not, as so many licensing laws now do, place artificial roadblocks in the path of work opportunities or squelch career aspirations by treating predictive opinions as final judgments.

's See also Musolf, Independent Hearing Officers: The California Experiment, $14 \mathrm{~W}$. Pol. Q. 195 (1961); Special Project-Fair Treatment for the Licensed Professional: The Missouri Administrative Hearing Commission, 37 Mo. L. Rev. 410 (1972).

"Indeed, these requirements may be mandated in some circumstances by the due process clause. See Withrow v. Larkin, 421 U.S. 35 (1975); Gibson v. Berryhill, 411 U.S. 564 (1973); Schlesinger Appeal, 404 Pa. 584, 172 A.2d 835 (1961). See also Davis, Withrow v. Larkin and the "Separation of Functions" Concept in State Administrative Proceedings, 27 AD. L. REv. 407 (1975); Note, Due Process Limitations on Occupational Licensing, 59 VA. L. REv. 1097, 1122-25 (1973). 